\title{
Bedrock Geology
}

of the Penn Yan and

Keuka Park Quadrangles

New York

GEOLOGICAL SURVEY BULLETIN 1161 -G

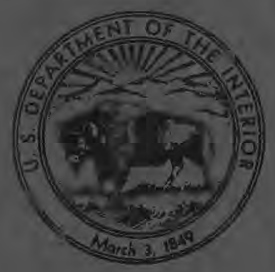




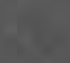




\section{Bedrock Geology}

\section{of the Penn Yan and}

\section{Keuka Park Quadrangles}

New York

By M. J. BERGIN

CONTRIBUTIONS TO GENERAL GEOLOGY

GEOLOGICAL S U R V EY B ULLETIN $1161-\mathrm{G}$

Lithologic descriptions and geologic maps of the Middle and Upper Devonian rocks in a part of the Finger Lakes region of New York State

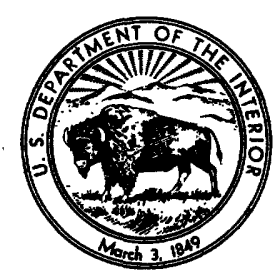




\section{UNITED STATES DEPARTMENT OF THE INTERIOR}

STEWART L. UDALL, Secretary

GEOLOGIGAL SURVEY

Thomas B. Nolan, Director

For sale by the Superintendent of Documents, U.S. Government Printing Office Washington, D.C. 20402 


\section{CONTENTS}

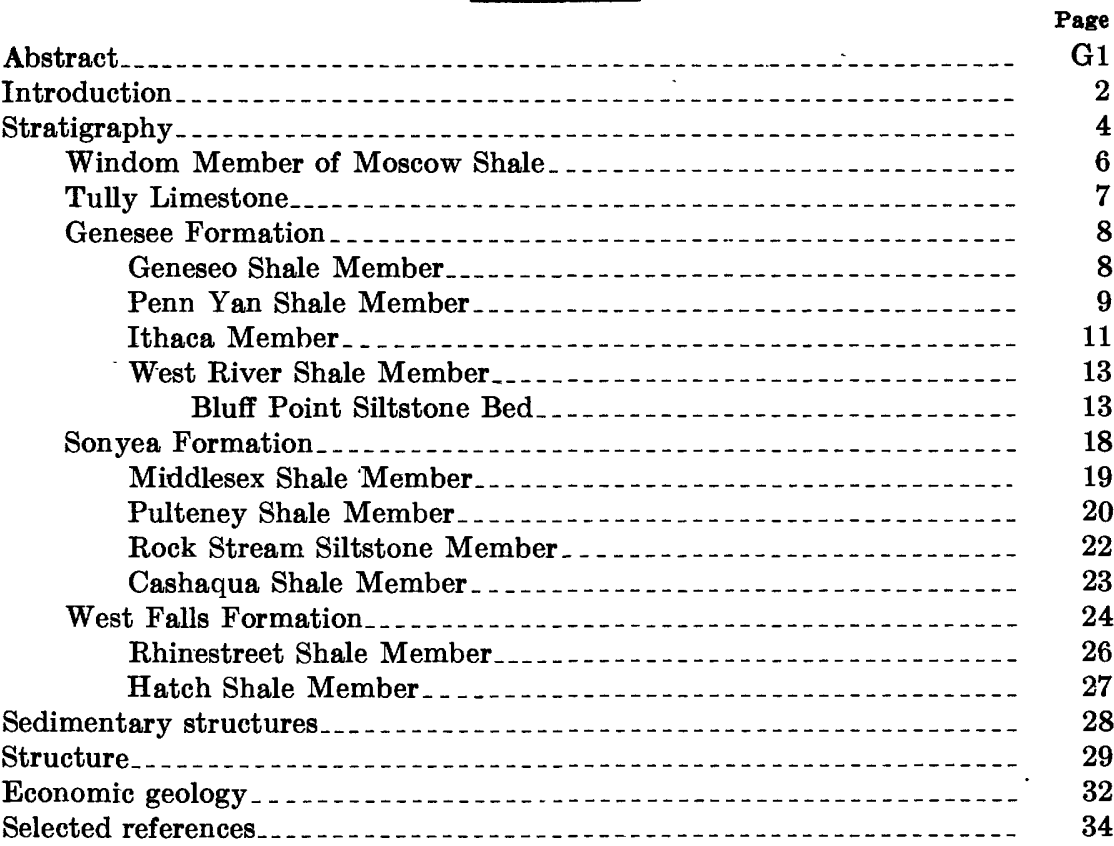

\section{ILLUSTRATIONS}

[Plates are in pocket]

Plate 1. Geologic and structure contour map of Penn Yan quadrangle.

2. Geologic and structure contour map of Keuka Park quadrangle.

3. Generalized columnar section.

Figure 1. Map of New York showing location of quadrangles

2. Typical convolute bedding in the Bluff Point Siltstone Bed.-

\section{TABLES}

TaBLe 1. Data for wells drilled in the Penn Yan and Keuka Park 



\title{
CONTRIBUTIONS TO GENERAL GEOLOGY
}

\section{BEDROGK GEOLOGY OF THE PENN YAN AND KEUKA PARK QUADRANGLES, NEW YORK}

\author{
By M. J. Bergin
}

\section{ABSTRACT}

The Penn Yan and Keuka Park quadrangles include about 110 square miles in parts of Yates and Steuben Counties in the Finger Lakes region of westcentral New York. This report is one of several that have been published during the past 10 years by the U.S. Geological Survey concerning studies of the lithologic sequence in the classic reference area for the Upper Devonian Series in North America. The sedimentary section exposed in the quadrangles is about 1,175 feet thick and ranges in age from late Middle Devonian to middle Late Devonian, it is composed of fine-grained deltaic sediments. The rocks, classified as black petroliferous shale, gray shale, mudrock, siltstone, and limestone, were deposited as intertonguing cyclicrecurring facies. As shown by regional studies, the beds of black petroliferous shale are easily recognized and are the most widespread lithologic units in the stratigraphic sequence. The strata are subdivided by using the bases of black shale units as formational contacts and by assigning the rank of member to the several individual lithologic units that occur between the units of black shale.

The stratigraphic sequence in the Penn Yan and Keuka Park quadrangles contains, in ascending order, the Windom Member of the Moscow Shale, the Tully Limestone, and the Genesee, Sonyea, and West Falls Formations. The Genesee Formation is subdivided into the following members, listed in ascending order: the Geneseo Shale (the basal black shale), the Penn Yan Shale, the Ithaca, and the West River Shale. The Renwick(?) Shale Member, which intertongues with the Penn Yan Shale Member, is recognized locally. The Bluff Point Siltstone Bed, which occurs about 25 feet above the base of the West River Shale Member, is an easily recognized convolutebedded siltstone, ranging from 0.2 to 0.4 foot in thickness, that serves as a useful key bed for stratigraphic correlation and structural control. Members that comprise the Sonyea Formation include, in ascending order: the Middlesex Shale (the basal black shale), the Pulteney Shale, the Rock Stream Siltstone, and the Cashaqua Shale. Only the two lower members of the West Falls Formation are present in the quadrangles; they are the Rhinestreet 
Shale Member (the basal black shale) and the overlying Hatch Shale Member. The boundary between the Middle and the Upper Devonian Series is tentatively placed at the top of the Geneseo Shale Member of the Genesee Formation.

Two prominent sets of vertical joints cut the rocks; the joints, on the average, trend $\mathrm{N} .72^{\circ}$ E. and N. $26^{\circ} \mathrm{W}$. Structure contours drawn on the base of the Middlesex Shale Member show that the dominant structural feature in the quadrangles is a westward-plunging anticline about 2 miles south of Second Milo. Associated synclines lie both south and north of the anticline. A northeast-trending fault, having a throw of about 40 feet down on the west side, has been inferred along the western side of Keuka Lake.

\section{INTRODUCTION}

The Upper Devonian rocks in western and central New York were investigated by J. F. Pepper, Wallace de Witt, Jr., and G. W. Colton as a part of the U.S. Geological Survey's study of the occurrence and origin of petroliferous black shale. By systematically measuring and describing closely spaced stratigraphic sections, these workers established regional correlations in the lithologic sequence that is in the classic reference area for the Upper Devonian Series in North America. Their recognition of cyclic repetition of facies formed the basis for subdividing the Upper Devonian sequence. They established a system of nomenclature in which previously published names were retained for individual units, but many of these units were redefined and correlated differently than had been done by previous workers. Detailed investigations were undertaken in the Penn Yan and Keuka Park quadrangles as one of several areas in which work was done to determine whether the units defined in the regional study, even though many are cyclic facies, could be both regionally and locally mapped with comparative ease and reliability.

The Penn Yan and Keuka Park quadrangles cover approximately 110 square miles in parts of Yates and Steuben Counties in westcentral New York (fig. 1). Penn Yan, the main village in the area, has a population of 5,481 and is the county seat of Yates County. Penn Yan is about 50 miles southeast of Rochester, 60 miles southwest of Syracuse, and 100 miles northwest of Binghamton.

The east arm of Keuka Lake, one of the Finger Lakes, extends the length of the Keuka Park quadrangle and projects a few miles into the southern part of the Penn Yan quadrangle (pls. 1,2). Most of the area is drained by streams that flow from the surrounding hills into the lake or into its outlet, which drains eastward to Seneca Lake. Kashong Creek in the northern part of the Penn Yan quadrangle and Big Stream in the southeast corner of the Keuka Park quadrangle also flow eastward into Seneca Lake and drain parts of 


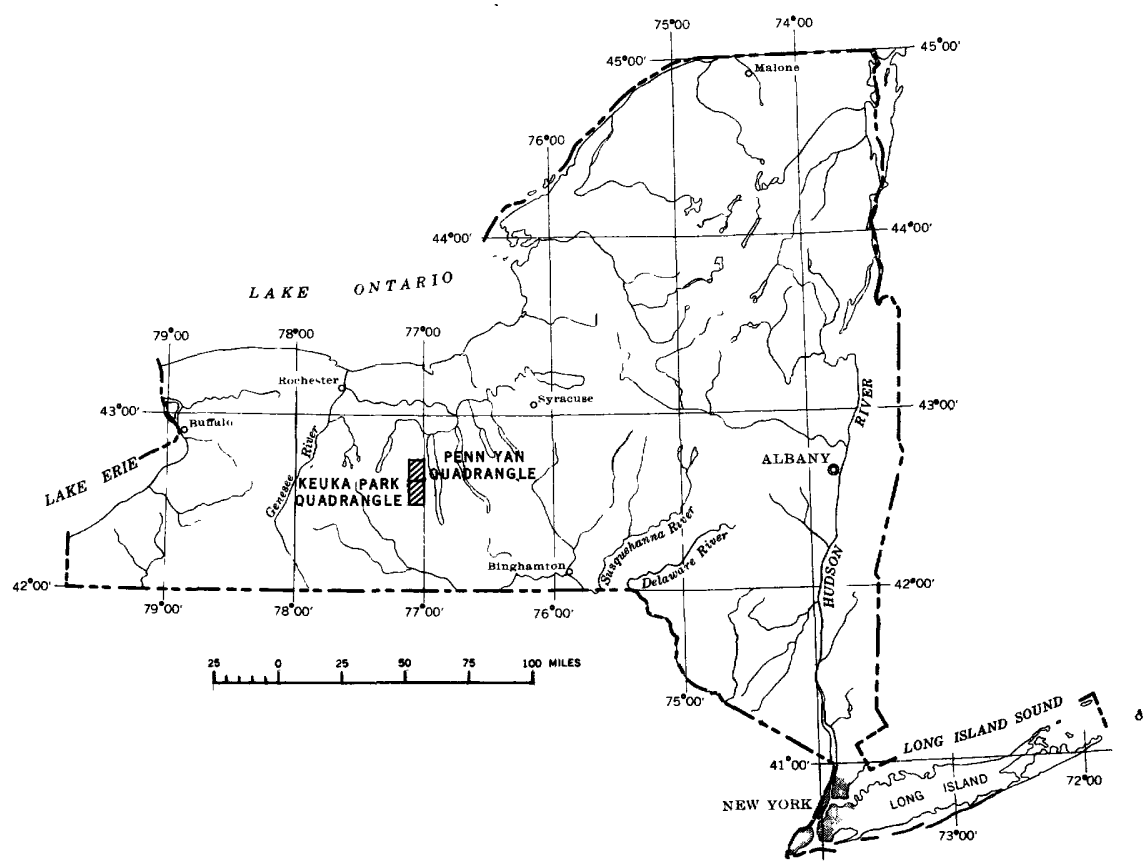

Figdre 1.-Map of New York showing location of the Penn Yan and Keuka Park quadrangles.

the area. Altitudes range from about 550 feet above sea level along the Keuka Lake Outlet at the eastern edge of the Penn Yan quadrangle to about 1,680 feet above sea level on the ridge at the southcentral edge of the Keuka Park quadrangle. Patches of forest dot the area, but most of the land has been cleared for pasture, farms, and vineyards. A network of state and county highways and private roads allows easy access to all parts of the area.

The quadrangles are in the Glaciated Allegheny Plateau section of the Appalachian Plateau province (Fenneman, 1938). Glacial drift and soil cover much of the area, and therefore, exposures of bedrock are largely restricted to steep sided, deeply incised streams, and to road cuts and quarries. Exposures of bedrock are few in the north half of the Penn Yan quadrangle because streams there have eroded through the glacial cover at few points.

The geology and paleontology of the Devonian rocks in western and central New York have been studied by many workers during the past 120 years. Many classic studies, both regional reconnaissance and locally detailed, were made prior to the 1930's. Reports published during that time which deal, at least in part, with the geology, paleontology, and geography of the Penn Yan and Keuka Park 
quadrangles and nearby areas include : Hall $(1839 ; 1840 ; 1841 ; 1843)$, Clarke and Luther (1904; 1905), Luther (1906), and Chadwick (1920).

The discovery of gas in the Wayne-Dundee field spurred geologic investigations that resulted in the following reports, which contain information for the area of the quadrangles: Torrey and others (1932), Fox (1932), Bradley and Pepper (1938), and Grossman (1944). More recent reports, which contain data for this area in New York, are: Pepper and de Witt $(1950 ; 1951)$, Pepper, de Witt, and Colton (1956), Colton and de Witt (1958), de Witt and Colton $(1959)$, and Sutton $(1959 ; 1960)$.

The results of investigations by other workers have been adequately summarized in the publications by Colton, de Witt, and Pepper cited above. The present report follows the revised correlations and redefined nomenclature used by de Witt and Colton (1959).

Fieldwork was done in the quadrangles during the autumn months of 1958 and 1959. Bedrock exposures were located by traversing the roads and stream beds. Contacts of the mapped units were plotted in the field on topographic base maps (scale of $1: 31,680$ ) at altitudes determined by altimeter or plane-table survey. Most of the planetable surveys were made by Pepper, de Witt, and Colton in previous years when they measured detailed stratigraphic sections throughout western and central New York. The writer, using steel tape, hand level, and Brunton compass, measured some additional stratigraphic sections. Altimeter readings were corrected daily for changes in pressure and temperature; a comparison of the altitudes determined by plane-table survey with those determined by altimeter showed a maximum error of less than 10 feet.

The author wishes to thank the many local residents who permitted access to their property during the months in which fieldwork was done. Special appreciation is given to J. F. Pepper, Wallace de Witt, Jr., and G. W. Colton, for orienting the writer in New York geography and geology, for the use of their unpublished data, for assistance throughout the investigations, and for critically reviewing the manuscript. Use of unpublished data compiled by Helen Nace during a search of the literature pertaining to Devonian stratigraphy in western and central New York was of considerable assistance in preparing the report.

\section{STRATIGRAPHY}

The bedrock sequence that crops out in the Penn Yan and Keuka Park quadrangles is about 1,175 feet thick and ranges in age from late Middle Devonian to middle Late Devonian. The predominant 
rock types that comprise the sequence are shale, mudrock, siltstone, and limestone. A few beds of very fine grained sandstone are present, but their occurrence is sparse. In this report, shale refers to rocks that exhibit fissility. Mudrock is used to describe those nonfissile rocks that are composed of clay-size particles or of a mixture of clay-size and silt-size particles; mudrock may or may not be bedded. The occurrence of siltstone ranges from highly resistant individual beds 0.1 to 2.0 feet thick that are interbedded in units of shale or mudrock to beds as much as 10 feet thick that make up units of siltstone as much as 80 feet thick. The 0.1 to 2.0 -feet-thick beds of siltstone are referred to as flagstone, a name commonly applied to these resistant beds because they were used for pavement, curbs, and foundations. The shale ranges from medium light gray through brownish gray and brownish black to black. Most brownish-black and black shale is petroliferous. Mudrock ranges from medium light gray to dark gray; some mudrock, and also some shale, has a greenish-gray tinge. Siltstone is commonly light gray or medium gray; limestone, which occurs as beds, nodules, and concretions, is commonly medium gray, but it has a bluish tinge at many localities. The strata range from even and well bedded to nonbedded or massive. Many of the rocks are irregularly bedded or gnarly bedded; some exhibit cross lamination and contorted bedding. Cementing materials in the rocks are mainly clay and calcium carbonate. Intersecting sets of parallel vertical joints cut the rocks; prolonged weathering and stream erosion along the joint planes in the more resistant rocks, such as the black shales, have produced steep, almost vertical cliffs along which joint blocks stand out in buttress and bastion shapes.

The Upper Devonian sequence in western and central New York has been subdivided into cyclic formations that include several members (de Witt and Colton, 1959, p. 2812). The bases of the black shale beds are sharply defined at most localities and are the only widespread, easily recognized lithologic units in the stratigraphic sequence. A formation is conveniently described as extending from the base of one widespread black shale to the base of the next stratigraphically higher widespread black shale. Where typically developed, the lithologic members that comprise the formation include, in ascending order, the basal black shale, the dark-gray shale, the light-gray to medium-gray siltstone, and the medium-gray calcareous shale and mudstone. Lithologic boundaries of the facies are commonly gradational both vertioally and laterally. Thin beds of black shale, gray shale, mudrock, siltstone, and limestone may be interbedded in units of dissimilar lithology. 
The stratigraphic sequence in the Penn Yan and Keuka Park quadrangles consists of, in ascending order, the Windom Member of the Moscow Shale, the Tully Limestone, and parts of three cyclic formations, the Genesee, Sonyea, and West Falls (pl. 3). The Genesee Formation is composed of the following members, in ascending order: the Geneseo Shale, the Penn Yan Shale, the Ithaca, and the West River Shale (pl. 3). The Renwick(?) Shale Member, which intertongues with the Penn Yan Shale Member, can be recognized locally. The Bluff Point Siltstone Bed is a useful key bed in the West River Shale Member. The Sonyea Formation includes the following members, from bottom to top, the Middlesex Shale, the Pulteney Shale, the Rock Stream Siltstone, and the Cashaqua Shale (pl. 3). The Parrish Limestone of Clarke and Luther (1904) was recognized at some localities in the Cashaqua Shale Member. The basal Rhinestreet Shale and overlying Hatch Shale were the only members of the West Falls Formation recognized in the quadrangles (pl. 3).

\section{WINDOM MEMBER OF MOSCOW SHALE}

The Windom Member of the Moscow Shale (Grabau, 1917, p. 946; Cooper, 1930, p. 232) crops out in a small area along the Keuka Lake Outlet at the eastern edge of the Penn Yan quadrangle (pl. 1). Only poor exposures of the upper 25 feet of the Windom are present in the quadrangles; however, the member is better exposed downstream along the outlet in the Dresden quadrangle to the east. The Windom Member is also exposed in Kashong Creek at Bellona, approximately three-quarters of a mile north of the northeastern corner of the Penn Yan quadrangle. The member consists predominantly of medium-gray, medium olive-gray, and dark-gray, irregularly bedded calcareous mudrock which weathers to a soft clay that is very slippery when wet. The part of the member exposed in this area contains several layers of medium-gray argillaceous limestone nodules and concretions. The nodules are spherical, discoidal, or ramose and may be as large as 0.4 foot thick and 0.8 foot in diameter. The concretions are commonly ovoid and may be as much as 1 foot thick, 1.5 feet wide, and 4 feet long. At some localities the upper 4 to 5 feet of the Windom is darker gray and more fissile; in the vicinity of Seneca Mills along the Keuka Lake Outlet the upper 4 feet is resistant, highly fissile petroliferous black shale. Fossils, mainly brachiopods, corals, crinoids, and trilobites, occur in both the mudrock and the concretions. The base of the Windom Member is not exposed in the quadrangles; the top is sharply marked by the base of the overlying Tully Limestone. 


\section{TULLY IIMESTONE}

The Tully Limestone (Vanuxem, 1839; Cooper and Williams, 1935) crops out in a small area along the Keuka Lake Outlet at the eastern edge of the Penn Yan quadrangle (pl. 1). The Tully is a very hard fine-grained, thinly bedded to massive, cobbly weathering medium dark-gray to dark bluish-gray fossiliferous limestone that ranges from 6 to 12 feet in thickness where exposed in this area. The limestone is also well exposed in Kashong Creek at Bellona just north of the Penn Yan quadrangle. Limestone of the Tully has been recognized in many of the wells drilled to test for oil and gas in the quadrangles. Both the top and the base of the Tully are sharply defined by an abrupt lithologic change from limestone to the black petroliferous shale of the overlying Geneseo Member of the Genesee Formation and to the medium dark-gray shale or mudrock of the underlying. Windom Member of the Moscow Shale. Fossils identified in the Tully are mainly brachiopods, corals, crinoids, and trilobites.

During the years since it was originally described by Vanuxem (1839), the Tully has been discussed in many reports; its lithology, fossil content, extent, thickness, correlatives, age, and relationship to rocks above and below have been considered. The more comprehensive reports that summarized the existing knowledge of the Tully include: S. G. Williams (1887), H. S. Williams (1890), Prosser (1899), Cooper (1930), Trainer (1932), and Cooper and Williams (1935). Cooper and Williams designated, on a faunal basis, three members in the Tully at the type locality in Onondaga County, N.Y.: the Tinkers Falls Member at the bottom, the Apulia Member in the middle, and the West Brook Member at the top. In their description of the Tully at Bellona, Cooper and Williams (1935, p. 795) placed the lower $21 / 2$ feet of limestone in the Apulia Member and the overlying $41 / 2$ feet of limestone in the West Brook Member.

The age of the Tully has been a subject of controversy. The Tully has been regarded as marking the boundary between the Upper Devonian and Middle Devonian Series; consequently, some authors have considered it to be the basal formation of the Upper Devonian, and others have considered it to be in the Hamilton Group and of Middle Devonian age. Cooper (1942, p. 1787) suggests that the Tully be regarded as Middle Devonian in age and that the Taghanic stage be made to include the Tully and its correlates. Hass (1959, p. 1615), on the basis of a study of conodonts in the Devonian strata of New York and Pennsylvania, placed the boundary between the Upper and Middle Devonian Series within the Geneseo Shale Member of the Genesee Formation which overlies the Tully. In the pres- 
ent report the Tully is considered to be Middle Devonian in age, and the boundary between Middle and Upper Devonian is placed near the top of the Geneseo Shale Member.

The Tully Limestone and the Windom Member of the Moscow Shale are shown as one unit on the geologic map (pl. 1) in this report because individual narrow outcrop patterns for the thin Tully Limestone and the upper 25 feet of the Windom, which is exposed in this area, would be difficult to distinguish at the map scale.

\section{GENESEE FORMATION}

Rocks of the Genesee Formation (de Witt and Colton, 1959) are exposed in the lower parts of many streams that drain into Keuka Lake north of Eggleston Glen and in the Keuka Lake Outlet and its tributaries (pls. 1, 2). The Genesee is exposed at only a few places in the area north of Penn Yan because that area is covered, for the most part, by glacial deposits. The formation has an average thickness of about 460 feet in the quadrangles. The four distinct lithologic members of the Genesee Formation that can be recognized and individually mapped in the Penn Yan and Keuka Park quadrangles are, in ascending order, the Geneseo Shale Member, the Penn Yan Shale Member, the Ithaca Member, and the West River Shale Member (pls. 1-3). The base of the formation is distinctly marked by the contact of the black shale of the Geneseo Member with the underlying Tully Limestone. The top of the formation is well defined at most localities by the contact of the gray shale of the West River Member with the black shale of the overlying Middlesex Shale Member of the Sonyea Formation.

\section{GENESEO SHALE MEMBER}

The Geneseo Shale Member (de Witt and Colton, 1959, p. 2816) is exposed in the Keuka Lake Outlet and its tributaries and in two tributaries of Kashong Creek in the extreme northeastern corner of the Penn Yan quadrangle (pl. 1). The thickness of the member could not be accurately measured along the outlet because the shale is covered at many places. In other stratigraphic sections measured in adjacent quadrangles the Geneseo ranges from 80 to 90 feet in thickness. In the Penn Yan quadrangle the member consists of homogeneous, highly fissile brownish-black and black petroliferous shale that contains, mainly in the upper half, numerous layers of limestone nodules and concretions. The nodules and concretions are spherical, discoid, or ovoid; their size ranges from nodules 0.2 foot in diameter to concretions as much as 1 foot thick, 1.5 feet wide, and 3 feet long. Many of the concretions are septerian. Pyrite 
occurs as disseminated crystals and scattered nodular masses in the shale; at many localities the weathered surfaces of shale are stained a typical orange brown. Conodonts and large petropods have been reported from the Geneseo Shale Member.

In the exposures in Kashong Creek west of Bellona and in the north eastern corner of the Penn Yan quadrangle, the top of the Geneseo Shale Member is the base of a medium-gray wavy-bedded calcareous siltstone bed 0.5 to 0.8 foot thick. The siltstone bed occurs in a slightly lighter colored shale and is about 1 to 3 feet above some large limestone concretions that occur in the top of the black shale. Many of the concretions at these particular localities are sinuous and attain a size as large as 1 foot thick, 2 feet wide, and 8 feet long. At the exposures in streams that drain from the south into Keuka Lake Outlet, the siltstone bed is only about 0.2 foot thick and the concretions below are ovoid to spherical but may attain a size as large as 1 foot thick and 2 feet in diameter.

The limestone concretions and calcareous siltstone at the top of the Geneseo Shale Member in this area have, in the past, been thought by some workers to be a part of the Genundewa Limestone (Clarke, 1903, chart). Many authors, among them Luther (1906), Fox (1932), Bradley and Pepper (1938), and Grossman (1944), described as the Genundewa a series of beds of argillaceous limestone, calcareous nodules and concretions, and calcareous siltstone at the top of the Geneseo black shale along the west shore of Seneca Lake. This correlation was made because the stratigraphic position of the beds relative to the black shale was similar to the position of the Genundewa Limestone in the type area at Genundewa Point on the east shore of Canandaigua Lake about 9 miles north of Naples, N.Y. However, regional correlations by de Witt and Colton (1959) show that the Genundewa Limestone (their Genundewa Limestone Member of the Genesee Formation) thins to the east from the type area at Genundewa Point and grades laterally into the Crosby Sandstone of Torrey (Torrey and others, 1932) in the area between Penn Yan and Gorham, N.Y. In the Penn Yan quadrangle the Crosby Sandstone is about 170 feet higher in the stratigraphic sequence than the top of the Geneseo Shale Member (pl. 3).

\section{PENN YAN SHALE MEMBGR}

The Penn Yan Shale Member (de Witt and Colton, 1959, p. 2818) is well exposed in the short streams that drain from the south into the Keuka Lake Outlet in the vicinity of Seneca Mills (pl. 1). It was from these exposures that Grossman (1944) originally described the rocks that he named the Penn Yan Tongue of the West River Shale. Rocks of the member are also present but poorly exposed in 
streams along the north side of the outlet, in streams in the northeastern corner of the Penn Yan quadrangle, and along the valley of the small stream that flows southward through Penn Yan into the outlet. The upper 20 to 50 feet of rocks in the member are exposed in streams that drain from the east into Keuka Lake north of Sunset Point (pl. 2). The Penn Yan Shale Member is about 170 feet thick in the vicinity of the Keuka Lake Outlet.

The dominant rock type in the Penn Yan Member is medium dark-gray to very dark-gray shale or mudrock; many distinct thin beds of black shale are present; siltstone occurs as very thin beds and stringers; limestone nodules occur abundantly throughout the member (pl. 3). In general, the lower one-third of the member is very dark-gray shale that grades upward into the medium darkgray shale and mudrock of the upper two-thirds of the member. Beds of black shale, which are more abundant in the lower third of the member, range from 0.1 foot to 4 feet in thickness and are characteristically iron stained orange brown when weathered. Beds of siltstone are more abundant in the upper half of the Penn Yan Member than in the lower half. The siltstone ranges from stringers less than 0.1 foot thick to beds as much as 1 foot thick. Siltstone beds may be laminated or massive; many are wavy bedded or crossbedded. Some siltstione beds are well cemented and resist weathering; others are poorly consolidated and weather readily. Limestone nodules, which are more abundant in the upper two-thirds of the member and which are heavily concentrated in the upper 10 feet of the Penn Yan at most localites, commonly have a variety of shapes including spheroid, discoid, ovoid, ramose, or pustulate. The nodules are composed of medium-gray argillaceous limestone and range from 0.1 to 0.8 foot in thickness, from 0.1 to 1.0 foot in width, and from 0.1 to 2.0 feet in length. Fossils observed in the member include pelecypods, brachiopods, cephalopods, and crinoids. Genera and species of fossils in the member are listed by Grossman (1944, p. 64-65).

A 4-foot thick bed of black shale, which was found at about the middle of the Penn Yan Shale Member in sections measured in a southern tributary to the Keuka Lake Outlet at Seneca Mills and in the stream between the airport and State Route 14A directly south of Penn Yan, has been correlated by de Witt and Colton (1959, p. 2824) with the Renwick(?) Shale Member of the Genesee Formation. They (de Witt and Colton, 1959, p. 2817, fig. 4) show that the Renwick pinches out in the vicinity of Keuka Lake, and they state (p. 2824) that this bed could not be distinguished from other beds of black shale in the Penn Yan Member northwest of the 
village of Penn Yan. The Renwick(?) was not mapped as a separate member in the present report because the black shale is very thin and the limit of its featheredge could not be located accurately. In the small area where the Renwick(?) could be recognized, it has been included in the Penn Yan Shale Member.

The top of the Penn Yan Shale Member in the Penn Yan and Keuka Park quadrangles is drawn at the base of the overlying Crosby Sandstone of Torrey (Torrey and others, 1932), as was done by Grossman (1944) and by de Witt and Colton (1959). This contact is well exposed at:altitude 860 in the stream between the airport and State Route 14A directly south of Penn Yan (Sartwell Ravine of older reports; the name Sartwell Ravine will be used hereafter in this report to identify this locality). The streams at Willow Grove, Raymond Point, Hewitt Point, and Sunset Point on the east side of Keuka Lake also contain good exposures of the contact (pl. 2).

\section{ITHACA MEMBFR}

The Ithaca Member (de Witt and Colton, 1959, p. 2821, 2825) is a sequence of predominantly siltstone and lesser amounts of very silty shale, silty mudrock, very fine grained sandstone, and black shale. The silty beds range from medium light gray to medium dark gray and contain mainly quartz mixed with mica and argillaceous material. The rocks range from laminated to massive, and many of the strata are crossbedded. Differing concentrations of calcareous cement and argillaceous material cause some beds to be hard resistant ledge formers and other beds to be soft, shaly, and nonresistant. Numerous resistant flagstones as much as 0.5 foot thick occur throughout the member. Calcareous siltstone concretions as much as 3 or 4 feet in diameter occur at random in many of the more massive siltstone beds. The Ithaca is fairly well exposed in streams on the east side of Keuka Lake from Sunset Point northward to Willow Grove and in the stream between State Routes 364 and 14A directly northwest of Penn Yan; upper parts of the member are exposed in streams on the east eide of the lake south of Sunset Point (pls. 1, 2). The Ithaca Member is about 120 feet thick in streambeds south of Willow Grove. According to de Witt and Colton (1959, p. 2817, fig. 4) the Ithaca thins to the west and thickens to the east. In the stream between State Routes 364 and $14 \mathrm{~A}$ just northwest of Penn Yan, only 80 feet of Ithaca was measured; however, the thin Ithaca section at that locality may be the result of faulting.

In the Penn Yan and Keuka Park quadrangles the base of the Ithaca Member is drawn at the base of the Crosby Sandstone of 
Torrey (Torrey and others, 1932). Grossman (1944) also used the Crosby to mark the base of this silty sequence that he called the Starkey Tongue of the Sherburne Formation but which de Witt and Colton (1959) have shown is the lateral extension of the Ithaca and not a tongue of the Sherburne. Fox (1932) described the Crosby Sandstone as having been named from its exposure at the hamlet of Crosby on the east shore of Keuka Lake, where the upper part of the sandstone crops out in a low cascade in the ravine. At the present site of Crosby (pl. 2) the Crosby Sandstone lies below water level of the lake and below erosion level of the stream bed. Inspection of the map included in Fox's report shows that, at the time Fox made his investigation, Crosby was located about 1 mile north of its present site. In the large ravine at the former site of Crosby, only the upper part of the sandstone is exposed; highway construction subsequent to 1932 has covered exposures that Fox may have reported in the vicinity of the former site of Crosby. The most southerly unquestioned exposure of the Crosby Sandstone seen by the author of the present report was in the small twin gullies about 1.6 miles north of the present site of Crosby (pl. 2). The sandstone is fairly well exposed in the streams at Sunset Point, Hewitt Point, Raymond Point, Willow Grove, Sartwell Ravine, and in the long southern tributary to the Keuka Lake Outlet at Seneca Mills (pls. 1, 2 ). In the area of the present report the Crosby ranges from 3 to 8 feet in thickness; at most localities it is composed of silt-size particles, but it does contain abundant very fine sand-size quartz grains, especially in the lower part. The grains are well cemented by calcite; Grossman (1944, p. 67) states that calcite is the predominant constituent of the rock in some places. Pyrite occurs abundantly as disseminated crystals and scattered nodular masses; upon weathering, the sandstone at many localities is stained a rusty orange brown. Brachiopods and crinoid stems are common in the Crosby; many of the fossils are iron enriched by secondary limonite that has been concentrated in the weathered rock. The Crosby is very hard and forms resistant ledges that cap waterfalls in many ravines.

The top of the Ithaca Member in the Penn Yan and Keuka Park quadrangles is drawn on the top of the highest siltstone bed below which the rocks are predominantly the more resistant siltstone, silty shale, and silty mudrock and above which the rocks are predominantly softer shale and mudrock. At many localities the contact is drawn arbitrarily because the rocks grade upward from siltstone to shale, but, in general, the contact occurs between 15 and 25 feet below the Bluff Point Siltstone Bed in the overlying West River Shale Member (pl. 3). 
The West River Shale Member (de Witt and Colton, 1959, p. 2819, $2822,2825)$ is exposed in most streams that drain into Keuka Lake north of Eggleston Glen (pl. 2). Rocks of the member are present over most of the area of the Penn Yan quadrangle but, because much of that quadrangle is covered by glacial material, good exposures are restricted to the streams on the west side of the valley of the stream that flows southward through Penn Yan into the Keuka Lake Outlet (pl. 1). In the area of this report the West River Shale Member ranges from 90 to 100 feet in thickness. The member is predominantly medium-gray to dark-gray shale and mudrock; as many as 10 beds of black shale ranging from 0.2 to 2.0 feet in thickness were found mainly in the lower two-thirds of the member (pl. 3 ). Most of the black shale beds can be correlated between stratigraphic sections and therefore they serve as useful marker beds. Siltstone, excepting the Bluff Point Siltstone Bed, is present in the shale only as irregularly spaced stringers and beds less than 0.1 foot thick. Argillaceous limestone nodules and concretions were found both separately and in layers at many randomly spaced stratigraphic horizons (pl. 3). The nodules and concretions, which may be spheroid, discoid, or ovoid, are commonly less than 1 foot thick and less than 2 feet in diameter, although some are as much as 4 feet in diameter.

As was described previously, the base of the West River Shale Member is arbitrarily drawn on the top of the highest siltstone bed representative of the Ithaca Member. The top of the West River Member is well defined at most localities by the sharp change from the softer, lighter-colored shale or mudrock of the West River to the harder, more fissile black petroliferous shale of the overlying Middlesex Shale Member of the Sonyea Formation.

\section{BLUFF POINT SIITSTONE BED}

In the Penn Yan and Keuka Park quadrangles a persistent bed of siltstone that ranges from 0.2 to 0.4 foot in thickness is present between 70 and 80 feet below the top, or approximately 20 feet above the base, of the West River Shale Member (pl. 3). The siltstone is medium light gray to medium gray, crossbedded to convolute bedded, calcareous, well cemented, hard, and resistant (fig. 2). Pyrite occurs as disseminated crystals in the siltstone and, upon weathering, stains the bed rusty orange brown. The upper surface of the weathered bed is irregularly wavy, hummocky, and pock marked. The siltstone bed forms a ledge across the ravines in mast stream exposures and protrudes beyond the overlying and underlying shale 
in cutbank or steep hillside exposures. Black shale beds as much as 2 feet thick are exposed in the 5-foot interval both above and below the siltstone bed at most localities; gray shale or mudrock :eparates the black shale beds and the siltstone bed. The following characteristics of the siltstone bed make it easy to recognize and very useful as a marker for stratigraphic and structural control in the rock sequence of this area: It is persistent over a wide area; it is the only siltstone bed more than 0.1 foot thick in the West River Shale Member; its thickness is relatively constant; it is characteristically bedded; it is a hard, resistant ledge former; and its stratigraphic interval to the top, or to the base, of the member is relatively constant in this area.

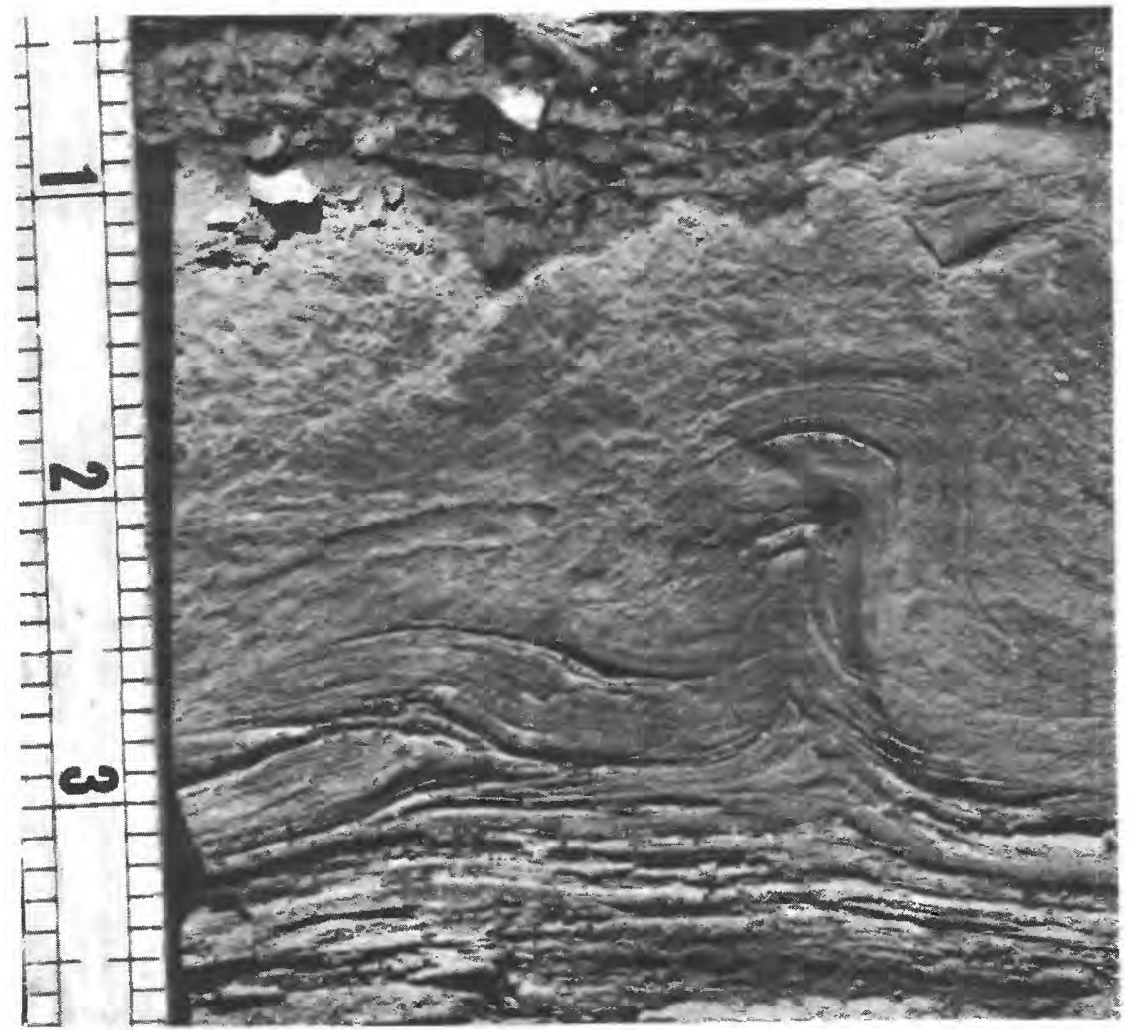

Figure 2.-Typical convolute bedding in the Bluff Point Siltstone Bed exposed about 4.25 miles south of Keuka Park along the road that borders Keuka Lake on the east side of Bluff Point. Scale is in tenths of a foot. 
This siltstone is undoubtedly the same bed that Torrey named the Bluff Point Flagstone, although he gave no description of it (Torrey and others, 1932, p. 16, figs. 6, 7). The bed was named either for Bluff Point, the southern end of the Peninsula between the east and west arms of Keuka Lake, where the flagstone is well exposed, or for the small village of Bluff Point in the northwest corner of the Keuka Park quadrangle, near which the flagstone crops out. Fox (1932, p. 683) described the bed and named it the Keuka Flagstone for "*** its excellent exposures on all shores of Keuka Lake $* * *$ * Neither Torrey nor Fox cited a type section for the bed. Bradley and Pepper (1938, p. 11, pl. 3) designated this thin flagstone as Horizon BP; Grossman (1944, p. 67) and Sutton (1959, p. 237) used the name Keuka Flagstone; de Witt and Colton (1959, p. 2825) referred to the bed as the Bluff Point Flagstone of Torrey and stated that it is present in more than 500 square miles of western and west-central New York, having been traced by them from Lake Erie eastward to Plum Point Creek, one-half mile west of the village of Himrod, N.Y. The author prefers the name Bluff Point Siltstone Bed because the publication of the work of Torrey and others (1932) a few months prior to that by Fox (1932) established a priority for the name Bluff Point. Bluff Point more precisely limits the type area in which the bed is exposed because the siltstone dips southward below water level of Keuka Lake at a point north of the junction of the east and west branches; consequently the bed is not exposed on all shores of Keuka Lake as was stated by Fox (1932).

The exposures in a small ravine on the east side of Bluff Point approximately 3.6 miles south of the intersection of the main streets at Keuka Park is designated here as the type section for the Bluff Point Siltstone Bed (pl. 2). Although this ravine is short, steep, and narrow, it was picked as the type section of the Bluff Point Siltstone Bed because a sequence of rocks more than 330 feet thick is exposed within a horizontal distance of 1,250 feet and because the stratigraphic relations of the Bluff Point Siltstone Bed to the Ithaca and West River Shale Members of the Genesee Formation and to the Middlesex Shale and Pulteney Shale Members of the Sonyea Formation can be seen clearly here. In the type section the Bluff Point Siltstone Bed is 0.3 foot thick and occurs 25 feet above the base and 72 feet below the top of the West River Shale Member. The stratigraphic sequence in the type section is as follows: 
Unit

Sonyea Formation (incomplete) :

Thickness

(feet)

Pulteney Shale Member (top covered) :

Shale, medium dark- to dark-gray, poorly exposed

Shale, dark-gray, fissile; contains medium-gray laminated and cross-laminated, moderately resistant beds of siltstone 0.05 to $0.4 \mathrm{ft}$ thick, spaced about 1 to $3 \mathrm{ft}$ apart

Shale, black, fissile, brittle

Shale, dark-gray; contains siltstone beds as in unit above the overlying black shale

Shale, black

Shale, dark-gray ; contains thinner and more closely spaced siltstone beds than shale units above.

Shale, very dark gray to black

Shale, dark-gray ; contains siltstone stringers and beds less than $0.1 \mathrm{ft}$ thick

Siltstone, medium-gray; interbedded with dark-gray silty shale in beds as much as $0.2 \mathrm{ft}$ thick

Shale, dark-gray, fissile ; contains stringers and beds of siltstone less than $0.1 \mathrm{ft}$ thick in lower $8 \mathrm{ft}$ and four siltstone beds as much as $0.2 \mathrm{ft}$ thick in upper $4 \mathrm{ft}$

Shale, very dark gray to black, highly fissile

Shale, dark-gray, soft; interbedded with mudrock and siltstone in beds 0.1 to $0.6 \mathrm{ft}$ thick

Shale, black

Shale, dark-gray, soft; interbedded with mudrock and siltstone as above; a moderately resistant bed of siltstone $0.6 \mathrm{ft}$ thick at top of unit

Shale, very dark gray; many nonresistant dark-gray siltstone laminae and stringers less than $1 / 4$ in. thick

Shale, black, fissile

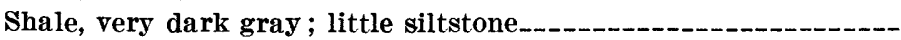

Shale, black, fissile, brittle

Shale, very dark gray; many nonresistant siltstone laminae and stringers less than $1 / 4$ in. thick; a few laminated siltstone beds as much as $0.1 \mathrm{ft}$ thick; a black shale bed $0.4 \mathrm{ft}$ thick at 6 $\mathrm{ft}$ above base; a black shale bed $0.6 \mathrm{ft}$ thick at $15.8 \mathrm{ft}$ above base

Thickness of measured part of Pulteney Shale Member

Middlesex Shale Member :

Shale, black, highly fissile, petroliferous, iron-stained rusty orange-brown; contains two beds of siltstone, each $1 / 2$ in. thick, at 4.3 and $4.6 \mathrm{ft}$ above base

Siltstone, medium-gray, laminated to cross-laminated; weathers platy-

Shale, black, fissile, brittle, very petroliferous, iron-stained rusty orange-brown, resistant 


\section{Unit}

Genesee Formation (incomplete) :

West River Shale Member :

Shale, medium dark-gray; grades to dark gray at top; a layer of ovoid limestone concretions $0.8 \mathrm{ft}$ thick and $2 \mathrm{ft}$ in diameter at $5 \mathrm{ft}$ above base; one discoid limestone concretion $0.5 \mathrm{ft}$ thick and $1 \mathrm{ft}$ in diameter at $10.5 \mathrm{ft}$ above base

Shale, medium dark-gray, fissile; many siltstone laminae and stringers less than $1 / 4$ in. thick; a few nonresistant siltstone beds as much as $0.1 \mathrm{ft}$ thick; two layers of discoid and ovoid limestone concretions as much as $0.7 \mathrm{ft}$ thick and $2 \mathrm{ft}$ long at base and $3 \mathrm{ft}$ above base

Shale, medium dark-gray, fissile; a layer of discoid limestone concretions $0.3 \mathrm{ft}$ thick and $2 \mathrm{ft}$ long at $5 \mathrm{ft}$ above base

Mudrock, slightly silty, dark-gray; contains a discoid limestone concretion, $0.3 \mathrm{ft}$ thick and $1 \mathrm{ft}$ in diameter, in middle

Shale, black, fissile, iron-stained brown

Shale, slightly silty, medium dark-gray

Shale, black, fissile, petroliferous, iron-stained rusty orangebrown; upper half contains siltstone laminae___-_._-_. 1.0

Shale, medium-gray to medium dark-gray, fissile; layers of spheroid, ovoid, and discoid limestone concretions at 7.4, $12,14.5$, and $20 \mathrm{ft}$ above base that range from 0.3 to $0.9 \mathrm{ft}$ in thickness and from 0.3 to $2 \mathrm{ft}$ in diameter or length

Shale, black, fissile, brittle-_._-_._- 1.4

Shale, medium dark-gray-_-_._-_._- 2.6

Mudrock, slightly silty, medium, dark-gray; lower $0.3 \mathrm{ft}$ moderately resistant___._-__-___- 1.1

Shale, black, fissile _._._._.

Mudrock, shaly, medium dark-gray to dark olive-gray, chunky; a layer of ovoid limestone concretions $0.8 \mathrm{ft}$ thick and $1.5 \mathrm{ft}$ long at $2 \mathrm{ft}$ above base

Shale, black, fissile, petroliferous _._._- 1.2

Mudrock, medium dark-gray, chunky-weathering-_._-_._-_-_.- 1.0

Bluff Point Siltstone Bed: siltstone, medium-gray, calcareous, hard, resistant; cross-laminated and highly contorted bedding; forms ledge across stream; iron-stained rusty brown on weathered surfaces_._._.

Mudrock, shaly, slightly silty, medium dark-gray__._._-_._-_.

Shale, black, fissile, brittle__-_____ 2.1

Mudrock, slightly silty, medium dark-gray, massive__._._._._._ 6

Shale, medium dark-gray

Mudrock, slightly silty, medium dark-gray________________ 1.6

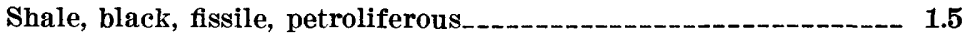

Shale, mudrock, and siltstone, interbedded, medium-gray, nonresistant; beds range from 0.1 to $0.8 \mathrm{ft}$ in thickness_._-_._-_- 6.5

Mudrock, silty, medium gray; contains beds of shaly silt-

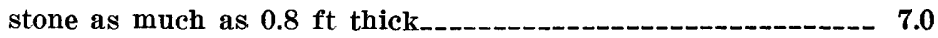

Total thickness of West River Shale Member._-_-_-_-_-_. 97.8 
Ithaca Member (base covered) :

Siltstone, medium light-gray to medium-gray, poorly bedded, hard, calcareous; weathers massive; forms cap of falls in stream

Siltstone, medium light-gray, laminated; some wavy bedded and crossbedded layers; weathers fissile to platy; moderately resistant in lower part of falls

Siltstone, medium-gray, massive

Siltstone, medium light-gray, laminated; much wavy bedding and crossbedding; weathers fissile to platy

Siltstone, medium olive-gray, hard, calcareous, massive, resistant; a 0.3-ft-thick shale bed in middle

Siltstone, medium olive-gray, laminated to thin-bedded; some wavy bedding and crossbedding; slightly calcareous, resistant; weathers to thin curved plates; forms falls in creek.

Mudrock, silty, medium-gray

Siltstone, medium light-gray, massive, calcareous, hard, resistant; forms cap of falls; a 0.3 -ft-thick shale bed $2.6 \mathrm{ft}$ above base

Mudrock, silty, medium-gray, massive; base concealed at culvert under road along west side of lake.

Thickness of measured part of Ithaca

Exposures at the type section of the Bluff Point Siltstone Bed are in a small ravine and could, in the future, become covered by debris; exposures in the following streams where the bed can be seen are therefore, designated as reference sections (pl. 2) :

1. A small ravine on the east side of Bluff Point 1 mile south of the type section and directly across Keuka Lake from Crosby; the Bluff Point is approximately at road level.

2. The relatively large ravine on the east side of Keuka Lake about 0.9 mile south of Crosby; the Bluff Point is at stream level directly west of the culvert under State Route 54.

3. Ravine on the east side of Keuka Lake at Crosby; the Bluff Point is exposed about 0.1 mile east of State Route 54 .

4. Ravine on the east side of Keuka Lake directly south of Keuka Lake Church about 0.8 mile north of Crosby; the Bluff Point is about 0.3 mile east of State Route 54 .

5. Ravine on the east side of Keuka Lake at Sunset Point; the Bluff Point is about 0.35 mile east of State Route 54 .

\section{SONYEA FORMATION}

In the Penn Yan and Keuka Park quadrangles the Sonyea Formation (Colton and de Witt, 1958) includes all the rocks between the base of the Middlesex Shale Member and the base of 
the Rhinestreet Shale Member of the overlying West Falls Formation (pl. 3). The Sonyea Formation is present in most of the area of the Keuka Park quadrangle and in the western half of the Penn Yan quadrangle (pls. 1, 2). The formation is fairly well exposed in most streams in this part of the area except in the northwest quarter of the Penn Yan quadrangle, where it is covered by glacial material. Four distinct lithologic units, which are recognized in the Sonyea Formation in the Penn Yan and Keuka Park quadrangles, are, in ascending order, the Middlesex Shale Member, the Pulteney Shale Member, the Rock Stream Siltstone Member, and the Cashaqua Shale Member (pl. 3). Because the Cashaqua Shale Member in this area is very thin, for convenience it has been mapped with the Rock Stream Siltstone Member as one unit on plates 1 and 2. The Sonyea Formation is about 425 feet thick in the vicinity of Eggleston Glen in the southern part of the Keuka Park quadrangle and thins northwestward to about 360 feet on the ridge to the west of Keuka Park. The thinning is attributed to a decrease in thickness of both the Pulteney Shale Member and the Rock Stream Siltstone Member. Both the base and the top of the Sonyea Formation are well defined. At the base the contact is a sharply marked lithologic change from the softer gray shale or mudrock typical of the West River Shale Member of the Genesee Formation to the harder, more resistant, highly fissile black petroliferous shale typical of the Middlesex Shale Member of the Sonyea Formation (pl. 3). The top of the Sonyea is marked by a similar lithologic change from the soft medium-gray to greenishgray, locally silty shale or mudrock of the Cashaqua Shale Member of the Sonyea Formation to the hard, more resistant fissile black petroliferous shale of the Rhinestreet Shale Member of the overlying West Falls Formation (pl. 3).

\section{MIDDLESEX SHALE MEMBER.}

The Middlesex Shale Member (Colton and de Witt, 1958) is exposed in most streams that drain into Keuka Lake north of Eggleston Glen, except those streams on the east side of the lake north of Hewitt Point (pls. 1, 2). The Middlesex is also exposed in several of the ravines on the west side of the valley between Penn Yan and Benton Station (pl. 1). The member ranges from 60 to 70 feet in thickness in the area of this report. The Middlesex Member is composed almost entirely of homogenous hard laminated black and brownish-black petroliferous shale (pl. 3). A small amount of dark-gray shale in layers less than 0.1 foot thick is interbedded in the black shale at some localities. Some siltstone occurs as nonresistant stringers and laminae less than 0.05 
foot thick at irregularly spaced stratigraphic positions throughout the member. As many as three beds of hard resistant carbonatecemented siltstone that may attain thicknesses of 0.4 foot are present in the lower 10 feet of the member at many localities. In some of the ravines between Eggleston Glen and Crosby the lowest of these siltstone beds is almost 1 foot thick. At a few exposures in the vicinity of Crosby and Sunset Point a number of discoid silty limestone concretions as much as 0.4 foot thick and 4 feet long are present in the lower 3 feet of the black shale. In a section along Plum Point Creek just east of the Keuka Park quadrangle, ovoid septarian limestone concretions as much as 1 foot thick and 2 feet long are abundant in several layers throughout the black shale of the Middlesex Member. The shale in the Middlesex is moderately resistant to weathering and, after having been exposed, is highly fissile and brittle. Two major sets of vertical joints transect the member approximately at right angles; where exposed in ravines, the shale forms very steep, almast vertical cliffs along the stream and steplike falls across the stream. Most weathered surfaces of the Middlesex are stained a rusty orange brown by iron oxides that probably formed by the weathering of disseminated and nodular masses of pyrite in the shale. Plant fragments were the only macrofossils found in the Middlesex Shale Member.

The lower boundary of the Middlesex Shale Member is clearly marked in the mapped area at the sharp contact of the black shale with the underlying lighter colored shale or mudrock of the West River Shale Member of the Genesee Formation. The upper boundary of the Middlesex is not as well defined as the lower boundary. The brownish-black to black shale that is typical of the Middlesex Member grades upward into the very dark gray shale representative of the overlying Pulteney Shale Member (pl. 3). In general, the boundary is drawn, arbitrarily at many localities, at a horizon above which very dark gray shale containing thin beds of resistant siltstone predominates over the more or less homogenous brownishblack to black shale containing only nonresistant stringers and laminae of siltstone.

\section{PULTENEY SHALE MEMBHR}

The Pulteney Shale Member (Colton and de Witt, 1958) overlies the Middlesex Shale Member in the Penn Yan and Keuka Park quadrangles (pl. 3). The Pulteney crops out in most of the same streams that were mentioned as localities of exposures for the Middlesex Shale Member (p. G19). The Pulteney is also exposed in the streams that drain into Keuka Lake at, and south of, Eggleston Glen. Ex- 
posures of the Pulteney also occur in streams on the ridge west of Chub Hollow at the eastern edge of the Keuka Park quadrangle. The Pulteney Shale Member thins in a northwesterly direction across the Penn Yan and Keuka Park quadrangles; it is about 175 feet thick in the ravine 0.9 mile south of Crosby on the east side of Keuka Lake, about 145 feet thick in the small ravine on Bluff Point across the lake from Crosby, and about 125 feet thick on the ridge due west of Keuka Park (pl. 2).

In general, the lower half of the Pulteney Member is predominantly dark gray shale which grades upward into the medium-darkgray and dark-gray, slightly silty shale that makes up most of the upper half of the member (pl. 3). Some lighter gray shale is commonly interlaminated with the very dark gray shale in the lower half of the member, and, similarly, some very dark gray shale is interlaminated with the lighter colored shale in the upper half. Numerous discrete beds of brownish-black and black shale, which range from 0.1 to 2.5 feet in thickness, are present in the Pulteney Member; at many localities the top bed of the member consists of black shale as much as 2.5 feet thick. Siltstone is interbedded in the shale as laminae and stringers less than 0.1 foot thick and as distinct beds as much as 0.5 foot thick. Generally siltstone is more abundant in the upper half of the member. Most of the siltstone beds are ripple marked on the top surfaces. Many of the siltstone beds are well cemented with calcium carbonate and form resistant ledges, some of which weather into large nodular blocks. Discrete limestone nodules or concretions, however, rarely are found in the Pulteney Shale Member. On the whole, the rocks in the Pulteney are soft and weather to a gentle sloping surface between the more resistant underlying Middlesex Shale Member and the overlying Rock Stream Siltstone Member. Typical stream exposures of the Pulteney are a series of steplike falls capped by calcareous siltstone or black shale beds. Banks of ravines that are cut through the Pulteney by small streams may be very steep because erosion is controlled at many localities by two major sets of closely spaced vertical joints that cut the shale at approximately right angles to each other. Stream erosion tends to remove the well-jointed soft Pulteney strata between the vertical joint planes, and the streams downcut rapidly with little lateral planation until they reach resistant beds in the Pulteney or the resistant black shale in the underlying Middlesex Shale Member.

The base of the Pulteney is not well defined because the shale of the Pulteney Member grades downward into the black shale of the Middlesex Member. The lower boundary of the Pulteney is 
arbitrarily drawn at a position above which the very dark gray shale that contains some interbedded lighter gray shale and siltstone characteristic of the Pulteney predominates over the relatively homogeneous black shale typical of the Middlesex. The boundary between the Pulteney Shale Member and the overlying Rock Stream Siltstone Member is sharply marked by the contact of the soft dark-gray or black shale of the Pulteney with the hard resistant calcareous siltstone bed at the base of the Rock Stream.

\section{ROCK STRPAM SILTSTONE MEMBER}

In the area of this report the Rock Stream Siltstone Member (Colton and de Witt, 1958) overlies the Pulteney Shale Member. The Rock Stream is well exposed in most streams on both sides of Keuka Lake at and south of Crosby (pl. 2). The member is less well exposed in small ravines on the ridge north of Big Stream and: west of Chub Hollow in the southeastern corner of the Keuka Park quadrangle, and in streams on the ridge west of Keuka Park in the northwestern corner of the Keuka Park quadrangle and the southwestern corner of the Penn Yan quadrangle (pls. 1, 2). The most complete section of the Rock Stream Member is exposed in the ravine on the east side of Keuka Lake about 0.9 mile south of Crosby. The lower part of the member is well exposed but is relatively inaccessible in the high falls in Eggleston Glen. Regionally, the Rock Stream Siltstone Member thickens to the southeast (Colton and de Witt, 1958). The southeastward thickening can be demonstrated in the Keuka Park quadrangle; the Rock Stream Member is about 155 feet thick on the ridge directly west of Keuka Park, and about 170 feet thick in the ravine 0.9 mile south of Crosby.

The Rock Stream Member is composed mostly of medium lightgray to medium-gray quartzose siltstone (pl. 3). The siltstone ranges from laminae less than 0.1 foot thick to discrete massive beds 8 feet thick. The thicker massive beds are usually well cemented with calcium carbonate and form resistant ledges. Spheroidal or ovoid calcareous siltstone concretions occur in some of the thick massive siltstone beds and may be as large as 2 feet thick and 4 feet in diameter. Some layers of siltstone are even bedded, but many are crossbedded. The crossbedded strata weather along the inclined bedding planes and spall off into large curved slabs. A large amount of medium dark-gray, very silty mudrock and very silty shale is interbedded throughout the member. These beds are usually less than 5 feet thick and are commonly interbedded with siltstone; when weathered, they form a 
series of thin alternating hard and soft layers. Some beds of dark-gray mudrock and shale, commonly less than 3 feet thick, are present; they are thicker and more abundant in the lower 20 feet of the member, and, upon weathering, they form soft layers that are commonly covered by slump blocks from overlying siltstone beds. A bed of black shale less than 1 foot thick occurs in the lower 5 feet of the member at a few localities.

The base of the Rock Stream Siltstone Member is sharply marked in the Penn Yan and Keuka Park quadrangles by a siltstone bed overlying the dark-gray shale of the Pulteney Member. At most localities the lowest siltstone of the Rock Stream is a bipartite bed composed of a lower layer about 0.5 foot thick and an upper layer about 1 foot thick, the two parts separated by about 0.4 to 0.7 foot of silty mudrock or silty shale. In some sections north of Eggleston Glen the basal siltstone is thinner but is still characteristically bipartite. Between the basal siltstone bed and the thick massive sequence of siltstone above it is about 10 to 15 feet of medium darkgray silty mudrock or silty shale that commonly contains one to three resistant beds of siltstone as much as 0.5 foot thick and a basal black shale less than 1 foot thick. In the Penn Yan and Keuka Park quadrangles the upper boundary of the Rock Stream Member is not well defined because the siltstone grades upward into the mudrock or silty shale of the overlying Cashaqua Shale Member. The boundary between the Rock Stream Siltstone Member and the Cashaqua Shale Member is arbitrarily placed at the top of the stratigraphically highest resistant siltstone bed representative of the Rock Stream, above which the rocks are predominantly mudrock or silty shale containing thin, relatively nonresistant beds of siltstone.

\section{CASHAQUA SHALE MEMBER}

The Cashaqua Shale Member (Colton and de Witt, 1958) overlies the Rock Stream Siltstone Member and is the uppermost member of the Sonyea Formation. Exposures of the Cashaqua are very poor in this area because the strata are present on the ridges, near or above the heads of most ravines, where outcrops are sparse because soil and glacial drift mantle the surface. The Cashaqua Shale Member underlies an appreciable area on the ridge east of Keuka Lake in the south-central part of the Keuka Park quadrangle and smaller areas on Bluff Point west of Keuka Lake and on the ridge west of Keuka Park (pls. 1,2). Exposures of the rocks, however, were found only in the ravines east of Keuka Lake about 0.9 mile south of Crosby and in the westernmost southern tributary to Eggleston Glen (pl. 2). The Cashaqua Shale Member has a maximum thickness of about 15 
feet where it is exposed in this area. Because it is so thin and because it is poorly exposed, the Cashaqua Member has been included, for convenience and ease of illustration, with the Rock Stream Siltstone Member on the geologic maps (pls. 1,2).

The Cashaqua Member is composed mainly of interbedded darkgray to dark greenish-gray mudrock and silty shale in beds 0.1 to 0.8 foot thick (pl. 3). Several nonresistant medium brownishgray siltstone beds that range from 0.1 to 0.5 foot in thickness are present in the member. Silty limestone nodules as much as 0.5 foot thick and 1 foot in diameter are scattered through the rocks. A 2.5foot thick, moderately resistant bipartite bed of dark brownish-gray, very silty limestone, parted in the middle by 0.6 foot of shale was found about 5 feet above the base of the member at some localities. Both the limestone and the interbedded shale contain numerous fragments of crinoid stems, pelecypods, and cephalopods. This bed may be representative of the Parrish Limestome of Clarke and Luther (1904, p. 31-32). The Cashaqua is softer and less resistant than the underlying or overlying members and is therefore usually covered by debris, even in stream valleys.

Mudrock and silty shale in the Cashaqua Member grade downward into the siltstone of the Rock Stream Member. The lower contact of the Cashaqua is arbitrarily placed at the top of the stratigraphically highest resistant siltstone bed above which the rocks are predominantly nonresistant mudrock, silty shale, and nonresistant siltstone. The upper boundary of the Cashaqua is well defined at most localities in the area; it is sharply marked by the contact of the hard fissile petroliferous black shale of the Rhinestreet Member of the West Falls Formation overlying the less resistant darkgray or greenish-gray shale or mudrock, or the brownish-gray siltstone typical of the Cashaqua Shale Member (pl. 3).

\section{WEST FALIS FORMATION}

In the Penn Yan and Keuka Park quadrangles, all the rocks above those in the Sonyea Formation are assigned to the West Falls Formation (Pepper, de Witt, and Colton, 1956). Only the lower part of the West Falls Formation is present in this area; the middle and upper parts of the formation have been removed by erosion. The West Falls underlies small areas on Bluff Point at the western edge of the Keuka Park quadrangle and on the ridge west of Keuka Park in the northwest corner of the Keuka Park quadrangle and the southwest corner of the Penn Yan quadrangle; the West Falls underlies a larger area on the ridge east of Keuka Lake in the south-central part of the Keuka Park quadrangle (pls. 
1, 2). The West Falls Formation is poorly exposed in this area because the strata crop out on high ridges above the altitude to which most streams have eroded through the cover of soil and glacial material. Rocks in the formation are best exposed in the westernmost southern tributary to Eggleston Glen (pl. 2).

Although the regional structure maps indicate that as much as 430 feet of the lower part of the West Falls Formation may be present in the Penn Yan and Keuka Park quadrangles, only the lowest 270 feet of strata are well enough exposed to permit accurate description of their sequence and lithology (pl. 3). Two members of the West Falls Formation can be recognized in the area of this report; they are the Rhinestreet. Shale Member at the base and the overlying Hatch Shale Member. The top of the Hatch Member is not exposed in the quadrangles. The formation is shown as one unit instead of as individual members on the geologic maps (pls. 1, 2) because the Rhinestreet Shale Member, which is only about 20 feet thick, is too thin to be accurately delineated at many places.

North of the village of Urbana, about 4 miles southwest of the Keuka Park quadrangle, the Grimes Siltstone Member, which overlies the Hatch Shale Member, is about 5 feet thick and lies about 417 feet above the base of the West Falls Formation (Pepper, de Witt, and Colton, 1956). The Grimes Siltstone Member was not shown to be present in the area of the Penn Yan and Keuka Park quadrangles by Pepper, de Witt, and Colton (1956, fig. 5). If the stratigraphic interval between the Grimes Member and the base of the West Falls Formation in the mapped area were 417 feet, the same as near Urbana, and if the siltstone persisted in the mapped area as a thin unit, the Grimes might possibly be present on the highest points on the ridge south of Barrington in the south-central part of the Keuka Park quadrangle. However, no exposures of the Grimes were located on the ridge. The regional trend of an eastward thickening of the Hatch Member from the area north of Urbana, when combined with the regional structure, indicates that the Grimes would lie at an altitude higher than that of the ridge top south of Barrington. The Grimes Siltstone Member thins rapidly to the east, north, and west from the type area near Naples, Ontario County, N.Y. (Pepper, de Witt, and Colton, 1956, fig. 5), and is probably absent by nondeposition in the Keuka Park quadrangle. Because the presence of the Grimes Siltstone Member in the Keuka Park quadrangle could not be adequately demonstrated, the member has not been shown on the geologic map (pl. 2) nor in the generalized stratigraphic section (pl. 3). In the area of this report, all rocks above the Rhinestreet Shale Member have been included in the Hatch Shale Member. 
The base of the West Falls Formation is sharply marked in the Penn Yan and Keuka Park quadrangles by the contact of the black shale of the Rhinestreet Member above with the dark-gray or greenish-gray mudrock and silty shale or with the brownish-gray siltstone of the Cashaqua Shale Member of the Sonyea Formation below. The upper boundary of the West Falls Formation is not present in the quadrangles.

\section{RHINESTREET SHALE MEMBER}

The Rhinestreet Shale Member (Pepper, de Witt, and Colton, 1956) is the basal unit of the West Falls Formation. The Rhinestreet is not known to be exposed in the Penn Yan quadrangle and is exposed at only a few places in the Keuka Park quadrangle. In the small ravine on the ridge directly west of Keuka Park the Rhinestreet Member is composed of about 18 feet of hard fissile brittle homogeneous petroliferous black shale (pl. 3). The black shale is underlain and overlain by siltstone. In the ravine 0.9 mile south of Crosby the lower half of the Rhinestreet Shale Member is covered. The upper half contains two beds of petroliferous black shale; the upper bed is 3 feet thick and the lower 1.3 feet thick; they are separated by a heterogeneous sequence of interlaminated mediumgray silty shale, light-gray siltstone, and black shale 5 feet thick. In the westernmost southern tributary to Eggleston Glen the Rhinestreet Member is 22 feet thick and contains five beds of black shale that are, in ascending order, 0.5, 0.9, 0.4, 1.2, and 3.8 feet thick. Medium dark-gray mudrock, dark-gray to very dark gray shale, and medium-gray siltstone, in beds 0.3 to 4 feet thick occur between the beds of black shale. The upper 2.4 feet of the member at this locality is very dark gray shale that contains siltstone laminae and stringers less than 0.1 foot thick; the thickest bed of black shale, 3.8 feet, lies directly below this very dark gray shale. In the ravine just south of Eggleston Glen, three beds of black shale, ranging from 1 to 2 feet in thickness, crop out in a vertical sequence about 12 feet thick at the position of the Rhinestreet Member; the rocks between the black shale beds are covered. Beds of black shale as much as 2 feet thick, which indicate the position of the Rhinestreet Member, are poorly exposed in small ravines on the ridge north of Big Stream.

Where exposed in the mapped area, the base of the Rhinestreet Shale Member is clearly marked. The black shale in the base of the Rhinestreet contrasts sharply with the dark-gray or greenishgray mudrock and silty shale or with the brownish-gray siltstone of the underlying Cashaqua Shale Member of the Sonyea Formation. The upper boundary of the Rhinestreet Shale Member is sharply marked at some localities in the area, but is poorly defined at others. 
The boundary is clearly marked at those localities where the black or very dark gray shale of the Rhinestreet is overlain directly by a bed of medium-gray nonbedded calcareous siltstone that ranges from 0.1 to 0.5 foot in thickness. Dark-gray shale and mudrock typical of the Hatch Member occur above the bed of siltstone. At some localities the siltstone is absent, and the black shale in the Rhinestreet grades upward into the dark-gray mudrock and shale in the Hatch Member; at these localities the upper boundary of the Rhinestreet is arbitrarily drawn on the top of the stratigraphically highest recognizable black shale bed.

\section{HATCH SHALE MEMBER}

The Hatch Shale Member (Pepper, de Witt, and Colton, 1956) is the uppermost stratigraphic unit of bedrock exposed in the Penn Yan and Keuka Park quadrangles. The upper boundary of the Hatch was not found in the mapped area, but as much as 410 feet of strata was calculated to be present. The name Hatch Shale Member was proposed to include the rocks between the Rhinestreet Shale Member and the Grimes Siltstone Member (Pepper, de Witt, and Colton, 1956). Although the Grimes Siltstone Member was not recognized in the mapped area, the name Hatch Shale Member is retained in this report for the rocks above the Rhinestreet Shale Member because these strata are the same lithologically as the strata included in the Hatch west of Keuka Lake near Urbana.

The Hatch Shale Member is present in the same areas that were listed for the occurrence of the West Falls Formation; they are (1) on Bluff Point west of Keuka Lake at the western edge of the Keuka Park quadrangle, (2) on the ridge west of Keuka Park in the northwestern corner of the Keuka Park quadrangle and the southwestern corner of the Penn Yan quadrangle, and (3) south of Barrington on the ridge between Keuka Lake and Big Stream in the south-central part of the Keuka Park quadrangle (pls. 1,2). The Hatch Member is poorly exposed in most of the mapped area because the strata are commonly covered by soil and glacial deposits on the ridges above the point where most streams have exposed bedrock. The lowest 250 feet of the Hatch Shale Member is well exposed in the westernmost southern tributary to Eggleston Glen (pls. 2,3).

The Hatch Member exposed in the mapped area is a heterogeneous sequence composed mainly of interbedded dark-gray silty shale, medium dark-gray to dark-gray silty mudrock, and mediumgray siltstone. This relatively soft sequence contains many beds of medium light-gray to medium dark-gray, evenly laminated and cross-laminated siltstone 0.1 to 1 foot thick that form resistant ledges (pl. 3). A few of the resistant beds in the upper part of the 
exposures are lighter gray and coarser grained, that is, very fine grained sandstone. Black shale occurs as stringers and beds less than 0.3 foot thick at irregularly spaced positions in the member. A few calcareous siltstone concretions as much as 0.3 foot thick and 0.5 foot in diameter are present in the strata. A typical streambank exposure of the Hatch Member consists of thin alternating resistant ledges and covered layers. Where exposed in beds of streams the rocks form a series of short low cascades capped by the resistant beds of siltstone.

The lower boundary of the Hatch Shale Member may or may not be sharply defined at different places in this area. The base is sharply marked at those localities where a hard resistant bed of siltstone directly overlies the black, or very dark gray, shale of the Rhinestreet Member. At other localities the dark-gray shale of the Hatch grades downward into the black shale of the Rhinestreet, and the boundary is arbitrarily drawn at the top of the stratigraphically highest black shale bed. The top of the Hatch Shale Member is not exposed, and probably is not present, in the Penn Yan and Keuka Park quadrangles.

\section{SEDIMENTARY STRUCTURES}

Flute casts, drag marks, and load casts (Kuenen, 1957) occur on the undersides of many of the beds of hard resistant siltstone that are exposed in the Penn Yan and Keuka Park quadrangles. The tops of many of the siltstone beds are ripple marked, and crossbedding is common in the siltstone. A study of the orientation of these sedimentary structures gives an indication of the direction of currents that were active during the time that the strata were deposited. Such studies on a regional basis have been made for the Devonian strata in western New York by Sutton (1959) and by G. W. Colton (oral and written communications, 1961).

Flute casts are oblong protruding ridges on the undersides of siltstone beds; typically, one end of the flute cast is abruptly blunt and bulbous where it merges with the siltstone bed and the other end is gradually tapered or flared. The blunt or bulbous end is believed to be oriented in the upcurrent direction. The flute casts in the Penn Yan and Keuka Park quadrangles average about 1 inch wide and are several inches long. Drag marks are long, even, parallel, usually straight protruding ridges on the undersides of siltstone beds. The long axes of drag marks are believed to be parallel to the current that formed them. However, the direction in which the current flowed cannot be determined from a study of the drag marks alone. Drag marks observed in the mapped area 
range from only a few hundredths of an inch to as much as 2 inches in width, and from a few inches to more than a foot in length. Load casts are irregular protrusions of various size, shape, and distribution on the undersides of siltstone beds. Load casts commonly have no individual elongation, but when considered collectively, several may be oriented in a particular direction. The load casts in this area range from a few hundredths of an inch to 2 inches in diameter.

It is difficult to obtain compass readings of the orientation of the sedimentary structures because the strata below the bed on which the feature occurs must be eroded away to expose the structures but the bed must not be disturbed by slumping. Approximately 40 orientation readings were obtained on the sedimentary structures in the strata in the Penn Yan and Keuka Park quadrangles. Numerous readings were obtained in the Penn Yan Shale Member of the Genesee Formation, the Rock Stream Siltstone Member of the Sonyea Formation, and the Hatch Shale Member of the West Falls Formation. Fewer readings were obtained in the Ithaca Member and on the Bluff Point Siltstone Bed in the West River Shale Member of the Genesee Formation; even fewer readings were obtained in the Middlesex Shale and Pulteney Shale Members of the Sonyea Formation and in the Rhinestreet Shale Member of the West Falls Formation. When plotted, the orientation of the sedimentary structures on the undersides of siltstone beds in the Penn Yan and Keuka Park quadrangles range from $36^{\circ}$ north of west to $43^{\circ}$ south of west; 60 percent of the readings are within $20^{\circ}$ of west. The orientation of the blunt ends of the flute casts and the dip of the crossbeds indicate that the currents flowed in a westerly direction. At a few localities where current ripple marks could be seen, a westerly direction of flow of currents was also indicated.

A shift in the direction of flow of currents during the time of deposition of the Rock Stream Siltstone Member is indicated by a change in the trend of the sedimentary structures. Features in the Rock Stream Member trend in a northwesterly direction and the orientation of the flute casts show that the currents flowed northwest, whereas the features in members both below and above the Rock Stream trend, predominantly, in a southwesterly direction and a current flowing to the southwest is indicated by the orientation of flute casts.

\section{STRUCTURE}

Two dominant sets of joints cut the bedrock in the Penn Yan and Keuka Park quadrangles. Joints in the hard, resistant, and brittle rocks are commonly straight and almost vertical; those in the softer shale and mudrock units may be curved and may dip through a 
range of angles, usually more than $45^{\circ}$. The joints in the better developed set trend from N. $63^{\circ}$ E. to N. $81^{\circ}$ E.; the average trend of the joints is $\mathrm{N}$. $72^{\circ} \mathrm{E}$. and the mode of the distribution lies between N. $72^{\circ}$ E. and N. $73^{\circ}$ E. Joints in the second set trend from N. $5^{\circ} \mathrm{W}$. to $\mathrm{N} .38^{\circ} \mathrm{W}$.; the average trend of these joints is about $\mathrm{N}$. $26^{\circ} \mathrm{W}$., but there is no well-defined mode to the distribution. Two subsidiary sets of joints are present in the rocks at some localities in the area. One subsidiary set, the better developed of the two, trends from N. $4^{\circ}$ E. to N. $12^{\circ}$ E.; the less distinct set, on which few readings could be obtained, trends between N. $52^{\circ} \mathrm{W}$. and N. $65^{\circ} \mathrm{W}$.

The average regional dip of Devonian strata in the Penn Yan and Keuka Park quadrangles is about 25 feet per mile to the southwest. It is modified locally by anticlines, synclines, and a fault, which are superposed upon the southwestern homocline. The structural features are depicted on plates 1 and 2 by lines of equal altitude drawn on the base of the Middlesex Shale Member (the base of the Sonyea Formation). The base of this member was picked as the datum because it is exposed in a larger part of the area than is any other easily recognizable datum. Contour lines are dashed where the altitude of the base of the Middlesex was determined by adding or subtracting the interval to other stratigraphic contacts.

A westward-plunging anticline is present in the northern half of the Keuka Park quadrangle (pl. 2). The rocks dip to the south, west, and north from the structural high about 2 miles south of Second Milo. A small amount of closure is probably present on this anticline (Bradley and Pepper, 1938, pl. 2). A narrow westward-plunging syncline near the southern edge of the Keuka Park quadrangle separates the anticline south of Second Milo from a dome or doubly plunging anticline to the south on which the WayneDundee gas field is located. A similar, but less-pronounced, westward-plunging syncline occurs along the boundary between the Penn Yan and Keuka Park quadrangles (pls. 1,2). A small structural terrace, which grades westward into a gently folded southern branch of the syncline, is present on the north flank of the anticline south of Second Milo. The syncline along the boundary between the quadrangles separates the anticline south of Second Milo from a series of gentle folds to the north in the east-central and southeastern parts of the Penn Yan quadrangle (pl. 1). North of these gentle folds the rocks dip southwest from a structural.high beyond the northeast corner of the Penn Yan quadrangle.

At exposures in stream beds throughout the mapped area, many minor anticlines were observed that are too small to be shown by the contour interval used on plates 1,2. These features range from tens to hundreds of feet in length, may be as much as a hundred 
feet wide, and may have a relief of as much as 5 feet. Typically, the rocks dip at angles ranging from $2^{\circ}$ to $30^{\circ}$ away from a fractured crest along the axis of the fold. In this area, most of these minor anticlines roughly parallel the trends of the two major sets of joints in the rocks. The folds are similar to those that were described as broken anticlines by Sutton (1951, p. 404) who proposed, for their origin, the adjustment to movement on possible faults in the Precambrian basement rocks. In the present study no definite eivdence to determine the origin of these minor folds was obtained, but the features are thought to have originated through tectonic stresses, rather than by surficial unloading of overlying sediments or glaciers, because the folds show no relationship to trends of stream channels or possible glacial troughs.

A northeast-trending fault having a throw of about 40 feet down on the west side has been inferred along the west side of Keuka Lake from a short distance south of Keuka Park to a few miles north of Penn Yan (pls. 1,2). The fault plane was not seen in the rocks. The stratigraphic section measured in the stream between State Routes 364 and 14A just northwest of Penn Yan showed that the Ithaca Member of the Genesee Formation, which is highly fractured at this locality, is only about 80 feet thick, whereas elsewhere in the mapped area the Ithaca is about 120 feet thick. The fault has been inferred to cut the Ithaca in this stream in such a way that about 40 feet of the member has been omitted. In a small ravine on the Penn Yan quadrangle, on the west side of Keuka Lake about 2.3 miles southwest of Penn Yan, dips as much as $30^{\circ} \mathrm{SE}$. occur in a highly fractured and disturbed zone in the Ithaca Member. The fault has been extended from the gully northwest of Penn Yan southwestward through the disturbed zone in this ravine. In the small gully between the cemeteries west of Penn Yan, the Bluff Point Siltstone Bed lies at an altitude higher than its altitudes in exposures to the north and to the south. The fault has been inferred to transect the rocks between the exposures of the Bluff Point in such a way that the exposure having the high altitude is in the upthrown block of the fault. The fault is assumed to die out to the southwest in the syncline in the vicinity of Keuka Park.

Repetition of the Tully Limestone in the Keuka Lake Outlet and the associated dips of the rocks in that vicinity have been discussed in the past by several authors. Trainer (1932, p. 14) summarized much of the earlier literature and pointed out that some authors proposed a sharp fold in the rocks and other workers proposed a fault to explain the structural disturbances. Trainer stated that the evidence for a north-trending fault through the 
locality was quite clear, even though the fault was not exposed. However, Torrey and others (1932, fig. 7) showed a sharp fold in the area;.Fox (1932, fig. 2) and Bradley and Pepper (1938, pl. 2) showed that an east-trending fault, having a downthrown northern block, was present in the vicinity of the Keuka Lake Outlet. The author of the present report examined the exposures at this locality and found that the Tully Limestone is present in the stream bed of the Keuka Lake Outlet at two places: (1) Seneca Mills, in the Penn Yan quadrangle, at an altitude of about 590 feet, and (2) Cascade Mills in the Dresden quadrangle, almost 1 mile east of Seneca Mills, at an altitude of about 515 feet. Few exposures of bedrock could be located between the two sites. The Tully, where exposed in southern tributaries to the outlet east of Cascade Mills, has a dip of about $2^{\circ} \mathrm{N}$. In streams north of the outlet east of Cascade Mills and in streams that drain eastward into Seneca Lake north of Dresden, the Tully has a regional dip to the south. In the vicinity of Seneca Mills the Tully is almost horizontal, dipping very slightly to the south. The presence of only a sharp fold to explain the structural disturbances cannot be ruled out because of the lack of exposures in the critical area, but the absence of eastward dips in the Tully tends to discount the existence of such a fold. In the opinion of the writer, a north-trending fault that crosses the outlet to the east of the Penn Yan quadrangle and is downthrown on the east best explains the repetition of the Tully Limestone and the associated rocks in the vicinity of the Keuka Lake Outlet. However, such a fault is not exposed in the area.

\section{ECONOMTC GEOLOGY}

Commercial use of the bedrock in the Penn Yan and Keuka Park quadrangles has not been extensive. The hard, resistant, relatively thin and slabby beds of siltstone have, in the past, been quarried locally for use as flagstone. At a few localities the siltstone beds have been quarried for use locally as foundation stone (Dickinson, 1903, p. 92). The petroliferous black shale of the Geneseo Member of the Genesee Formation, the Middlesex Member of the Sonyea Formation, and the Rhinestreet Member of the West Falls Formation could be mined and used as a source for petroleum if economic conditions and demand should become suitable. Thirteen wells have been drilled to test for oil and gas in the Penn Yan and Keuka Park quadrangles (table 1; see pls. 1, 2 for locations). The wells were drilled to test the Oriskany Sandstone, which is the producing zone in the Wayne-Dundee gas field to the south. Total depths of the wells range from 1,245 to 2,818 feet; all the test wells have been dry holes; many tapped salt water. 


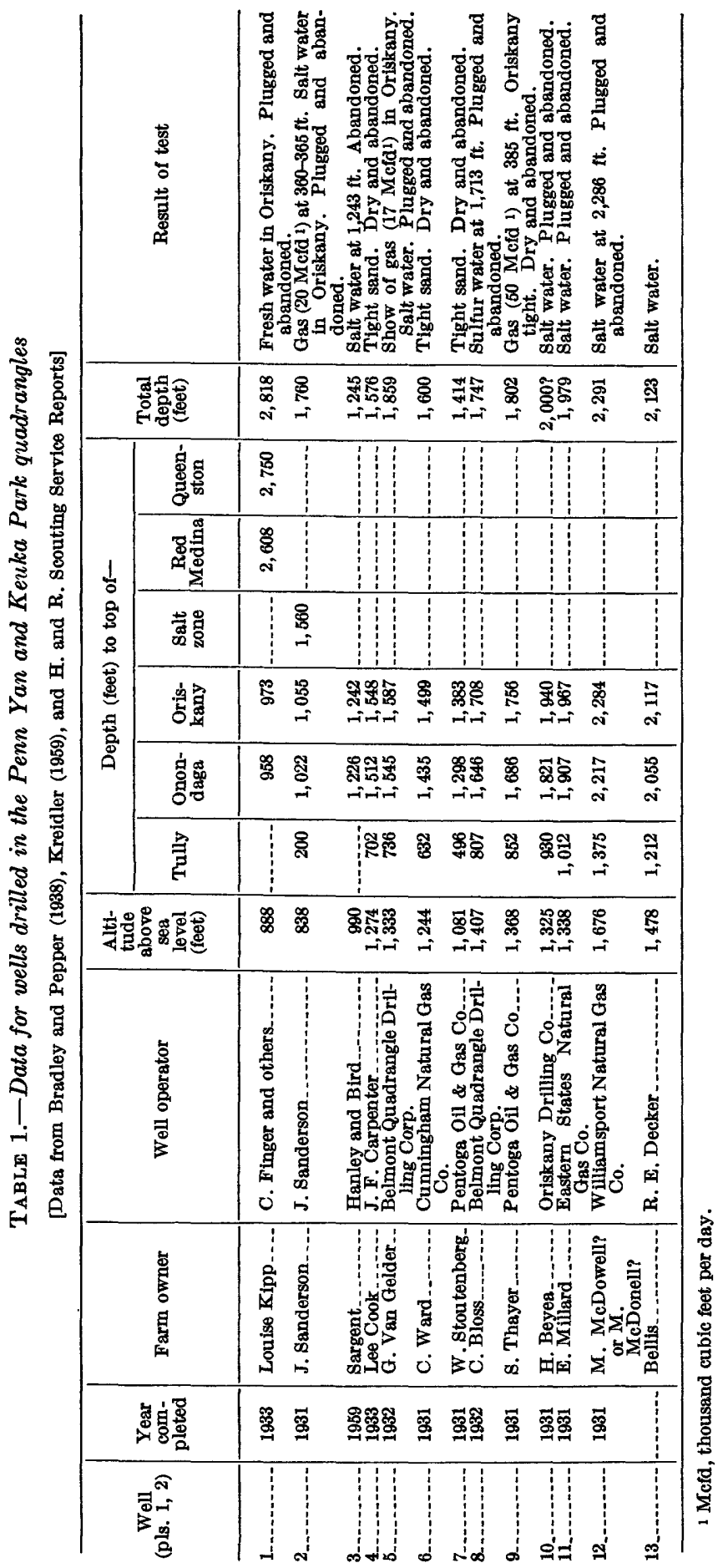


Sand and gravel have been excavated from the surficial glacial material at many places in the northern part of the Penn Yan quadrangle for use, locally, in construction. Many of the sand and gravel pits are marked by the standard symbol on the topographic base map used in the compilation of the geologic map (pl. 1).

\section{SELECTED REFERENCES}

Bradley, W. H., and Pepper, J. F., 1938, Structure and gas possibilities of the Oriskany sandstone in Steuben, Yates, and parts of the adjacent Counties, pt. 1 of Geologic structure and occurrence of gas in part of southwestern New York: U.S. Geol. Survey Bull. 899-A, p. 1-68, map.

Chadwick, G. H., 1920, Large fault in western New York: Geol. Soc. America Bull., v. 31, p. 117-120.

Clarke, J. M., 1903, Classification of New York series of geologic formations: New York State Mus. Handb. 19, 26 p.

Clarke, J. M., and Luther, D. D., 1904, Stratigraphic and paleontologic map of Canandaigua and Naples quadrangles: New .York State Mus. Bull. 63, 76 p., map.

1905, Geology of the Watkins and Elmira quadrangles: New York State Mus. Bull. 81, 29 p., map.

Colton, G. W., 1956, Bedrock geology of the Hamburg quadrangle, New York: U.S. Geol. Survey Geol. Quad. Map GQ-97.

Colton, G. W., and de Witt, Wallace, Jr., 1958, Stratigraphy of the Sonyea formation of Late Devonian age in western and west-central New York: U.S. Geol. Survey Oil and Gas Inv. Chart OC-54.

Cooper, G. A., 1930, Stratigraphy of the Hamilton group of New York: Am. Jour. Sci., 5th ser., v. 19, p. 116-134, 214-236.

- Ch., 1942, Correlation of the Devonian sedimentary formations of North America: Geol. Soc. America Bull., v. 53, no. 12, pt. 1, p. 1729 1793.

Cooper, G. A., and Williams, J. S., 1935, Tully formation of New York: Geol. Soc. America Bull., v. 46, no. 5, p. 781-868.

de Witt, Wallace, Jr., 1956, Bedrock geology of the Eden quadrangle, New York : U.S. Geol. Survey Geol. Quad. Map GQ-96.

de Witt, Wallace, Jr., and Colton, G. W., 1953, Bedrock geology of the Silver Creek quadrangle, New York: U.S. Geol. Survey Geol. Quad. Map GQ-30.

1959, Revised correlations of lower Upper Devonian rocks in western and central New York: Am. Assoc. Petroleum Geologists Bull., v. 43, no. 12, p. 2810-2828.

Dickinson, H. T., 1903, Quarries of bluestone and other sandstones in the Upper Devonian of New York State: New York State Mus. Bull. 61, $113 \mathrm{p}$.

Fenneman, N. M., 1938, Physiography of the eastern United States: New York, McGraw-Hill Book Co., 691 p.

Fox, I. W., 1932, Geology of part of Finger Lakes region, New York: Am. Assoc. Petroleum Geologists Bull., v. 16, no. 7, p. 675-690.

Grabau, A. W., 1917, Stratigraphic relationships of the Tully limestone and the Genesee shale in eastern North America: Geol. Soc. America Bull., v. 28, no. 4, p. 945-958. 
Grossman, W. L., 1944, Stratigraphy of the Genesee group of New York: Geol. Soc. America Bull., v. 55, no. 1, p. 41-76.

Hall, James, 1839, Third annual report of the fourth geological district of the State of New York: New York Geol. Survey Ann. Rept. 3, p. 287339.

1840, Fourth annual report of the survey of the fourth geological district: New York Geol. Survey Ann. Rept. 4, p. 389-456.

- 1841, Fifth annual report of the fourth geological district: New York Geol. Survey Ann. Rept. 5, p. 149-179.

- 1843, Geology of New York, pt. 4, comprising the survey of the fourth geological district: Albany, N.Y., Carroll and Cook, printers to the Assembly, 653 p., maps.

Hass, W. H., 1959. Conodont faunas from the Devonian of New York and Pennsylvania [abs.] : Geol. Soc. America Bull., v. 70, no. 12, pt. 2, p. 1615.

Luther, D. D., 1906, Geology of the Penn Yan-Hammondsport quadrangles: New York State Mus. Bull. 101, p. 37-58, map.

Kreidler, W. L., 1959, Selected deep wells and areas of gas production in eastern and central New York: New York State Mus. Sci. Service Bull. $373,243 \mathrm{p}$.

Kuenen, Ph. H., 1957, Sole markings of graded graywacke beds: Jour. Geology, v. 65, no. 3, p. 231-258.

Pepper, J. F., 1954, Bedrock geology of the Hornell quadrangle, New York : U.S. Geol. Survey Geol. Quad. Map GQ-37.

Pepper, J. F., and de Witt, Wallace, Jr., 1950, Stratigraphy of the Upper Devonian Wiscoy sandstone and the equivalent Hanover shale in western and central New York: U.S. Geol. Survey Oil and Gas Inv. Prelim. Chart 37.

1951, Stratigraphy of the Late Devonian Perrysburg formation in western and west-central New York: U.S. Geol. Survey Oil and Gas Inv. Chart, OC-45.

Pepper, J. F., de Witt, Wallace, Jr., and Colton, G. W., 1956, Stratigraphy of the West Falls Formation of Late Devonian age in western and westcentral New York: U.S. Geol. Survey Oil and Gas Inv. Map. OC-55.

Prosser, C. S., 1899, Classification and distribution of the Hamilton and Chemung series of central and eastern New York, pt. 2: New York State Geologist Ann. Rept. 17, p. 65-315.

Sutton, R. G., 1951, Stratigraphy and structure of the Batavia quadrangle: Rochester Acad. Sci. Proc., v. 9, p. 348-408, map.

1959, Use of fiute casts in stratigraphic correlation: Am. Assoc. Petroleum Geologists Bull., v. 43, no. 1, p. 230-237.

1960, Stratigraphy of the Naples group (Late Devonian) in western New York: New York State Mus. Sci. Serv. Bull. 380, 56 p.

Torrey, P. D., Fralich, C. E., Young, W. H., Jr., Brewer, Charles, Jr., and Phillippi, P. M., 1932, The geology of New York and northern Pennsylvania : Am. Petroleum Inst. Paper 826-4a, 19 p.

Trainer, D. W., Jr., 1932, The Tully limestone of central New York: New York State Mus. Bull. 291, 43 p.

Vanuxem, Lardner, 1839, Third annual report of the geological survey of the third district: New York Geol. Survey Ann. Rept. 3, p. 241-285.

Williams, H. S., 1890, The Cuboides zone and its fauna; a discussion of methods of correlation: Geol. Soc. America Bull., v. 1, p. 481-500.

Williams, S. G., 1887, The Tully limestone, its distribution and its known fossils : New York State Geologist Ann. Rept. 6, p. 13-29. 
